\title{
Relationships between Students' Socioeconomic Status, Parental Support, Students' Hindering, Teachers' Hindering and Students' Literacy Scores: PISA 2018
}

\author{
Ömür, Çoban ${ }^{1, *}$ \\ ${ }^{1}$ Faculty of Education, Karamanoglu Mehmetbey University, Karaman, Turkey \\ *Correspondence: Faculty of Education, Karamanoglu Mehmetbey University, Karaman, Turkey. Tel: \\ 90-505-237-7889. E-mail: cobanomur@gmail.com
}

Received: June 5, $2020 \quad$ Accepted: July 4, $2020 \quad$ Online Published: August 18, 2020

doi:10.5430/wje.v10n4p45 URL: https://doi.org/10.5430/wje.v10n4p45

\begin{abstract}
This research was conducted in Turkey and it examined the relationships between fifteen-year-old students' PISA 2018 literacy scores and student-level and school-level variables. This study aimed to examine the relationships between students' hindering, teachers' hindering, socioeconomic status, parental support and student achievement. The research is a correlational study. A relational screening model was used in this research. Six thousand eight hundred and ninety students from one hundred and eighty-six schools in twelve regions of the Nomenclature of Territorial Units for Statistics (NUTS) Level 1 joined PISA 2018 in Turkey. OECD selected these students randomly. In PISA 2018, school sampling was determined by a stratified random sampling method. Teachers' hindering, students' hindering questionnaires are from the school principals' questionnaire and the parental support questionnaire was taken from the student questionnaire. Additionally, students' genders and their socioeconomic status were taken from the background questionnaire. To analyze these variables, a hierarchic linear model was used. Multilevel structural modeling (MSEM) was selected and Bayesian estimation with latent variables was performed. There are direct relationships between students' genders, socioeconomic status, teachers' hindering behaviors, students' hindering behaviors, parental support and Turkish students' reading skill scores. There is also an indirect relationship between teachers' hindering behavior and students' reading skill scores via students' hindering behavior.
\end{abstract}

Keywords: students hindering, teachers hindering, socioeconomic status, parental support and student achievement

\section{Introduction}

Many researches on Educational Administration (EA) have been conducted on school processes, structures and outcomes. There is a scholarly interest in understanding school outcomes, student achievement and quality in education by examining a variety of variables, such as the roles of school principals (Heck \& Hallinger, 2010; Ozdemir \& Demircioglu, 2015; Sun \& Leithwood, 2012), the roles of teachers (Darling-Hammond \& Youngs, 2002; Hindman \& Stronge, 2009, Staiger \& Rockoff, 2010), the roles of parents (Aslanargun, 2007; Gonida \& Cortina, 2014) and students' socio demographic variables, i.e. SES (Abotsi, Yaganumah, \& Obeng, 2018; Özdemir, 2019) and gender (Freeman, 2004; Machin \& Mc Nally, 2005).

Recent studies show that supportive environments are the driving forces to improve student learning outcomes (Bryk, Sebring, \& Allensworth, 2010; Robinson, Lloyd, \& Rowe, 2008). On the other hand, a negative learning environment causes unwanted teacher and student behaviors in schools (Schab, 1991; Turner, Reynolds, Lee, Subasic \& Bromhead, 2014; Üzbe \& Bacanl1, 2015). One of them is self-hindering. Self-hindering behaviors have negative impacts on student achievement, their well-being and their self-confidence (Török, Szabó, \& Tóth, 2018; Yu \& McLellan, 2019). Additionally, teachers' self-hindering attitudes affect teachers' self-efficacy, professional development and teaching performance in a negative way (Goddard, Goddard, \& Tschannen-Moran, 2007). Moreover, a large proportion of our knowledge about what variables influence student achievement points out the two vital variables: parental support and students' socioeconomic status (SES). National and international researches have taken place, such as Transition to High School Exam, PISA, TIMMS, TALIS, etc. indicate that SES and parental support are the predictors of student achievement (Ministry of National Education [MEB], 2019; 
Organization for Economic Co-operation and Development [OECD], 2019a). These exams and researches show that gender is an effective predictor to explain student achievement. There is a lot of theoretical knowledge on student success, but empirical studies on the variables that affect student achievement are scarce. It is necessary to enrich empirical studies on student achievement by modeling the variables that explain it. This paper aims to focus on students, teachers' hindering behaviors and parents' supportive attitudes, SES and gender and their effects on student achievement in Turkey. In other words, the present study is trying to provide an understanding of the extent to which variables in the Programme for International Student Assessment (PISA), 2018 are vital to explain Turkish students' literacy scores in a better way. Unlike many OECD countries, Turkish students do not have high scores in PISA and the rank of Turkey in PISA is not at a desired level. Turkish educationalists and policy makers try to adapt the measurement and evaluation system and try to assess students' academic improvement more effectively. For instance, they make up assessment teams in all the provinces to monitor students' achievements. Additionally, in recent years, they have transformed the questions in national exams into PISA questions. Turkish students pulled out their best level since they participated in the literacy scores in a PISA exam thanks to these changes. The aim of this paper is to examine the relationships between student-level variables, school-level variables and students' literacy scores. The finding of this study could contribute considerably to the growing knowledge base regarding the antecedents and outcomes of student achievement in broader international contexts. It could also contribute to societies and countries with similar educational policies and structures.

\section{Conceptual Framework}

The conceptual framework of this study is based on the past literature in EA. This body of knowledge base is concerned predominantly with the antecedents and/or outcomes of student achievement (Bellibaş, 2016; Darling-Hammond, 2000; Dee, 2007; Harris \& Sass, 2011; Özdemir, 2019; Sar1er, 2016). The first line of research focuses on the variables - parental support, gender and SES - that affect student achievement at an individual level (Figure 1); whereas the second line focuses on the roles of teachers, students and parents and SES on students' literacy scores at the school level (Figure 2). Firstly, the relationships between students' gender, SES, parental support and their literacy scores were investigated. Secondly, the relationships between teachers' and students' hindering and students' literacy scores were examined.

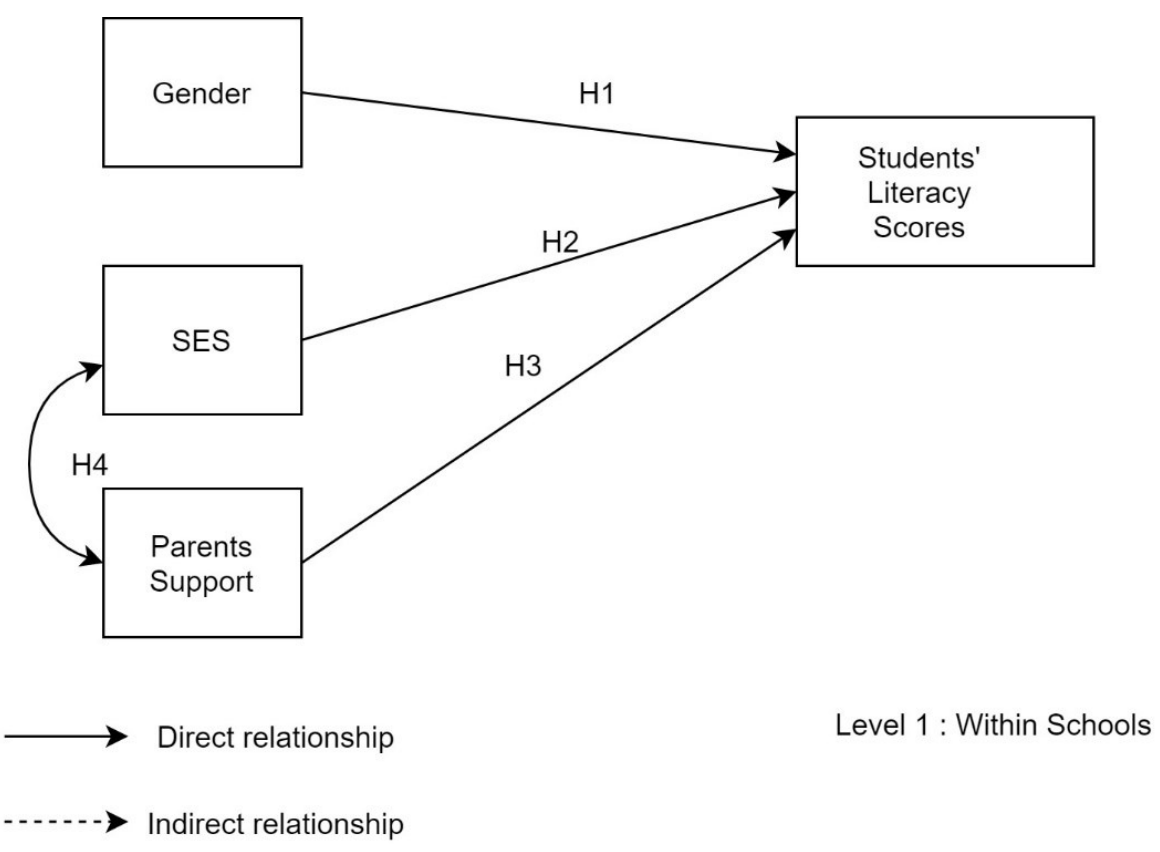

Figure 1. Research Model (Student level) 


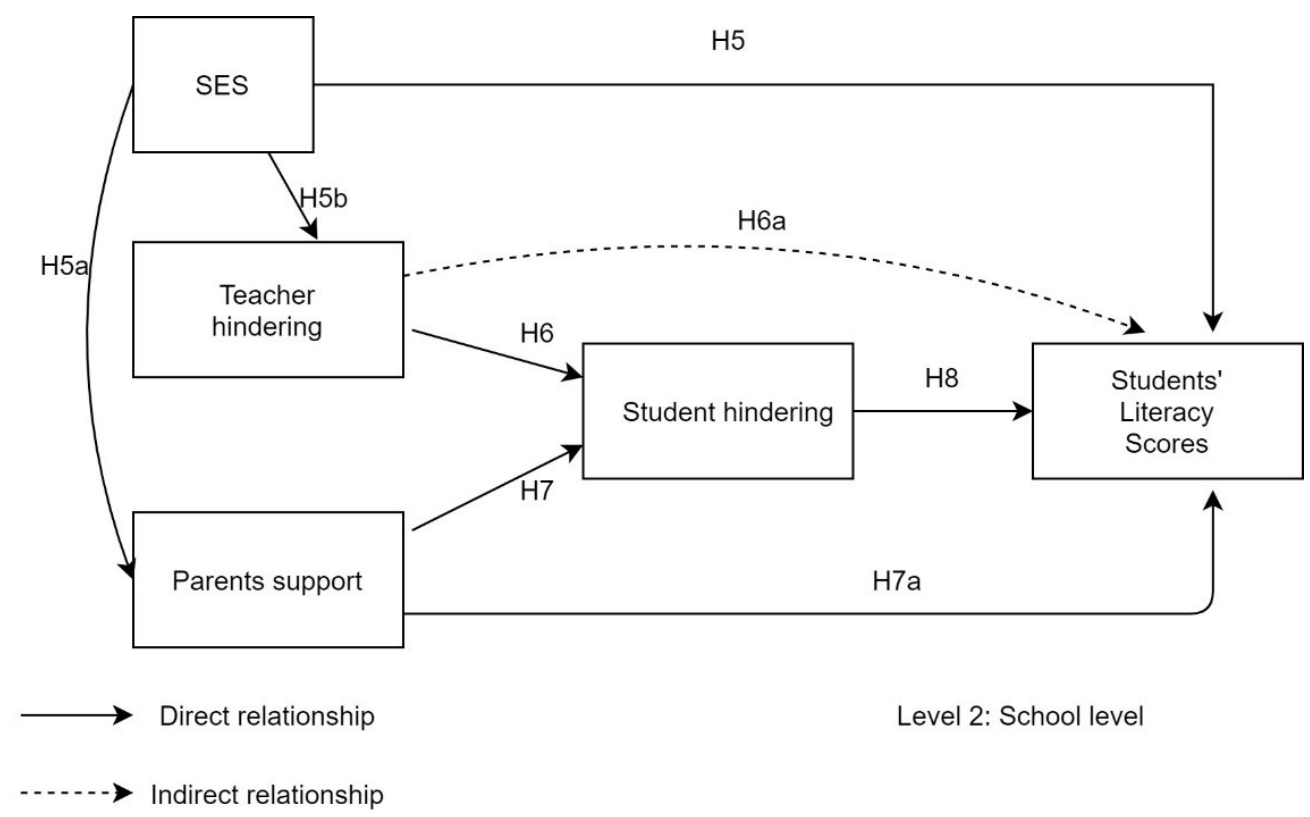

Figure 2. Research Model (School level)

The following section provides a discussion of the theoretical and empirical basis of each hypothesis in the conceptual model. Firstly, students' level variables - students' gender, SES, parental support and their literacy scores were analyzed. Then, school level variables - teacher hindering, student hindering, parental support and SES were examined and the impact of them on students' literacy scores were given.

\subsection{Student Achievement and Gender}

The term 'student achievement' is defined as the student's reaching the desired level in the education process and getting high marks from the exams she attends (Onuk, 2007). In literature, researchers classify the variables that affect student academic achievement under two main categories: the variables at the student level and those at the school level. A vast majority of the studies on student achievement emphasize that the gender gap in student achievement is one of the vital factors to explain the success (Charles \& Luoh, 2003; Freeman, 2004; Machin \& Mc Nally, 2005; OECD, 2019a). These studies underline that the average scores of girls exceed that of boys at all grades. For example, in the USA, women have been consistently better educated than men since the mid-1970s. In Turkey, the rates of female and male students with reading skills proficiency levels differ slightly from each other. The highest level of boy and girl students' presence is at the 2nd level. However, it was determined that female students were found to be higher between the 3rd and 6th levels. The average reading score of male students was calculated as 453.1 and the average score of female students as 478.4 (MEB, 2019). Hence, the relationship between students' gender and their literacy scores were examined. As a result, in this study, the first hypothesis is:

\section{H1: There is a significant relationship between Turkish students' gender and their literacy scores.}

\subsection{Student Achievement and SES}

Previous studies indicate that the socio-economic level of families (Klomegah, 2007; Sarier, 2016), the parents' education level and their behaviors (Koutsoulis \& Campbell, 2001; Pomerantz, Ng, \& Wang, 2006; Pomerantz, Wang, \& Ng, 2005), the personal characteristics of students (Kız1ldağ, 2009), the school culture (Patterson, Perry, Decker, Eckert, Klaus, \&Wendling, 2003; Schoen \& Teddlie, 2008), and teachers' performance (Darling-Hammond, 2000; Dee, 2007) have an effect on student achievement. Although there are many variables that affect student achievement, in the present study, we are trying to draw into a conceptual framework the socio-economic level, gender, students' and teachers' hindering behaviors and parents' supportive behaviors.

Education has an impact on economic growth by increasing the quality of human capital, which is one of the basic inputs in the production functions of countries and companies (Barro, 2013; Barro \& Lee, 2013; Goldin \& Katz, 2008). The quality of human capital can be evaluated based on the academic success of the students. Therefore, a large number of studies are needed to reveal the relationships between the socio-economic level and the academic success of students. The socio-economic situation (SES) covers not only the economic benefits of individuals, but 
also their access to education, social security, opportunities and the privileges provided to people as well as their quality of life. Many studies have been conducted on the relationship between socioeconomic level and education (Brown, Wohn, \& Ellison, 2016; Buckingham, Wheldall \& Beaman-Wheldall, 2013; Hanushek, 1997; Sirin, 2005). These studies show that the academic skills of the students who belong to families with a low socio-economic level are less than those of families with a high socio-economic level. Moreover, Aikens and Barbarin (2008) also showed that children of families with a low socio-economic level experience inadequate cognitive development, language, memory and emotional process problems and that their students have a low income in their future lives and experience health-related problems. The inadequate education and dropout rates of the students decrease student achievement on the one hand and affect the socio-economic level of society on the other hand (Abotsi et al., 2018). The results of PISA 2018 show that students with a high socio-economic level achieve higher scores compared to their peers with a lower socio-economic level. Additionally, PISA 2018 research showed that students with a low academic performance are more likely to come from a lower socioeconomic background (OECD, 2019a). The low level of impact of SES on educational outcomes is important in terms of equality in education. According to the 2018 PISA results in Turkey, the impact of SES on student achievement has declined. This shows that education quality and equal opportunities in education progress positively in Turkey (MEB, 2019). Hence, the relationship between SES and students' literacy scores was investigated and, as a result, the second and the fifth hypothesis of this study are:

H2 (within the school level): there is a significant relationship between SES and Turkish students' literacy scores.

H5 (between schools): there is a significant relationship between SES and Turkish students' literacy scores.

\subsection{Parental Support}

Substantial research evidence (e.g. Chen, 2008; Gottfried, Fleming, \& Gottfried, 1994; Wentzel, 1998) has revealed that parental support does help improve students' achievements and makes students more successful in their school life. On the other hand, if the family neglects the student's educational life and ignores supporting them, students will get low scores and maybe, at the end, they will give up their educational life. Aslanargun (2007) stated that the main reason for parents' lack of interest is based on not establishing a healthy communication with their children in previous periods. According to him, parents do not care enough about their children's psycho-social and cognitive development and just take care of their biological needs. Gonida and Cortina (2014) emphasized that parents should motivate their children and they should supervise their children's homework and their school life closely. On the other hand, if parents ignore their children's school and social lives, children have bad habits, violate their friends and fail their classes. Moreover, current researchers (Ong, Phinney, \& Dennis, 2006) have identified the determinants of student achievement including the influence of parental support. Families with a high socioeconomic level are more sensitive to supporting their children (Özdemir, 2019). The results of PISA 2018 indicate that parental support influences student achievement in a positive way. Additionally, PISA 2018 research claimed that families with high socioeconomic levels are more conscientious and they tend to support their children's school life more (OECD, 2019a). In the research, parental support was framed with the PISA 2018 experts' definitions. In their definition, they expressed the parental support as: support for children's educational efforts and achievements, encouraging them to overcome the difficulties in their school life and trying to make them confident. Therefore, I researched the relationship between parental support, student hindering behaviors and students' literacy scores. The relationship between SES and parental support were also examined. As a result, the hypotheses are:

H7: there is a significant relationship between parental support and students' hindering behaviors.

H3 (within school level): there is a significant relationship between parental support and Turkish students' literacy scores.

H7(a) (between schools): there is a significant relationship between parental support and Turkish students' literacy scores.

H4 (within the school level): there is a significant relationship between SES and parental support.

H5a (between schools): there is a significant relationship between SES and parental support.

\subsection{Teachers' Hindering Behaviors}

In schools, teacher collaboration is sometimes below the desired level because of hindering factors (Leonard, 2002). These hindering factors are derived from personal, group, organizational and structural characteristics. Personal hindering factors are mainly about lack of skills and knowledge for training, resistance to collaboration and inability to work in a team etc. (Rone, 2009). Group hindering factors are, for instance, unclear group goals, lack of leadership 
behaviors, lack of communication, undesired team size etc. Structural factors, such as time pressure, work pressure and pressure of standardization also influence teacher hindering (Smetser, 2007; Westheimer, 2008). Organizational characteristics include isolation and individualism in the school culture and norms of professional autonomy (e.g. Gajda \& Koliba, 2008; Goddard et al., 2007). The studies on teacher hindering state that the higher a teacher's collaboration level is, the higher the students' performance level. On the other hand, when teachers face hindering factors and are unable to overcome them, students' academic performances are low (Helstad \& Lund, 2012; Vangrieken, Dochy, Raes, \& Kyndt, 2015). What is more, studies underlined that we see teachers' hindering behaviors less in the schools in the regions where the socio-economic level is high (Carneiro, 2008; Ünal, Yildirim, \& Çelik, 2010; Xitao \& Chen, 2001) because, in these regions, parents are conscientious and can create hidden pressure on teachers and the school. In the study, the framework of PISA 2018 experts on teachers' hindering was used. They exhibited teachers' hindering behaviors as follows: ignoring individual students' needs, absenteeism, resistance to change, strict behaviors to students and not being well prepared for classes. As can be seen, these hindering behaviors mainly cover their personal characteristics and these behaviors trigger students' hindering behaviors and block student achievement indirectly. However, families with a high socioeconomic level decrease teachers' hindering behaviors by exerting hidden pressure on the teachers and the school. Therefore, the relationships between teachers' hindering behaviors, students' hindering behaviors and their literacy scores were investigated. As a result, the sixth hypothesis of the study is:

H6: There is a significant relationship between teachers' hindering behaviors and students' hindering behaviors.

H6 (a): There is a significant indirect relationship between teachers' hindering behaviors and Turkish students' literacy scores.

I also examined the relationship between SES and teachers' hindering behaviors. Therefore, another hypothesis is:

H5(b): There is a significant relationship between SES and teachers' hindering behaviors.

\subsection{Student Hindering}

If the school climate is supportive and positive, the trust level among school actors such as teachers, students, parents and school administrators is high (Hoy, Smith, \& Sweetland, 2002). The school climate is also positively related to students' self-confidence (Hoge, Smit, \& Hanson, 1990). In a positive school climate, students have less absenteeism and their anxiety levels decrease (Hendron \& Kearney, 2016). Additionally, they have less substance addiction and fewer psychiatric problems (LaRusso, Romer, \& Selman, 2008). On the other hand, when the perception of the school climate is negative, it is likely that unwanted attitudes or behaviors may occur in the school. They would not exhibit collaborative behaviors and we would observe some undesired behaviors such as less or no participation in the learning process, lack of communication among them, ignoring subjects, low self-efficacy perception and self-handicapping (Özgüngör, 2008; Smith, Sinclair, \& Chapman, 2002; Üzbe \& Bacanl, 2015; Virtanen, Kivimaki, Luopa, Vahtera, Elovainio, Jokela, \& Pietikainen, 2009). Student hindering behaviors have negative effects on their academic performance and well-being (Török, Szabó, \& Tóth, 2018). Moreover, they cause exam anxiety (Barutçu, Yıldırım \& Demir, 2019) and emotional exhaustion (Akın, 2012). In the paper, the definition of PISA 2018 experts on students' hindering were used. They expressed students' hindering behaviors as follows: truancy, bullying other students, usage of illegal drugs and alcohol, lack of respect for teachers, skipping classes and not being attentive. As is seen, these hindering behaviors block student achievement. Therefore, the relationship between student hindering behaviors and their literacy scores have been researched. As a result, the eighth hypothesis is:

H8: There is a significant relationship between students' hindering behaviors and Turkish students' literacy scores.

\section{Method}

\subsection{Research Model}

This research was conducted in Turkey and examined the relationship between fifteen-year-old students' PISA 2018 literacy scores and some individual and school-level variables. A relational screening model was used in this research. In this model, analyses were done via correlation or comparison. The researcher(s) investigates whether the variables change together and, if there is a change, they see how this happens (Daniel, 2012). In this study, the relationship between Turkish students' PISA 2018 literacy scores and their gender, SES, parental support, teacher hindering and student hindering behaviors were examined. The data of the research have a two-level hierarchical structure consisting, first, of schools and then of students within schools. Given this context, a two-stage sampling method was used. In the first stage, student level variables were investigated. In the second stage, school level variables and student achievement were examined. 


\subsection{Participants}

Six thousand eight hundred and ninety students from one hundred and eighty-six schools in twelve regions of the Nomenclature of Territorial Units for Statistics (NUTS) Level 1 in Turkey joined PISA 2018. The International Center of OECD selected these students randomly. In PISA 2018, school sampling is determined by the stratified random sampling method. The layers are: the type of school, the school's location and the gender distribution and NUTS Level 1. Participation rates of students in the PISA 2018 sample varied between $1.6 \%$ and $20.2 \%$ by region. $49.6 \%$ of the sample are female students. $78.8 \%$ of the students are in the 10 th grade, $17.7 \%$ of them in the 9th grade and $2.9 \%$ of them in the 11 th grade. $43.7 \%$ of the 15 -year-old students are in the Anatolian high school, $31.1 \%$ of them are in vocational and technical high schools and $13.7 \%$ of them are in religious high schools.

\subsection{Data Collection Tools}

Teachers' hindering and students' hindering questionnaires were taken from school principals' questionnaire and the parental support questionnaire was from the student questionnaire. Additionally, students' gender information and SES were taken from a background questionnaire. For calculating the SES score, the PISA 2018 experts' formula that includes parents' educational status, number of books, number of siblings, family income and some facilities that students have in their houses, was used. The reading skills score was calculated from the student questionnaire results that were composed of ten possible values (Plausible Value) generated from the answers given by students. However, school survey results obtained through the school principal were used for school level data. The data were accessed from the PISA 2018 database (http://www.oecd.org/pisa/data/2018database/).

\subsubsection{Dependent Variable: Students' Reading Literacy Scores}

In PISA 2018, individualized testing was used to measure student success more accurately. The questions in the booklets used in PISA 2015 and previous applications have a fixed structure. In other words, the location of the questions in the booklets has been determined in advance. However, in the field of PISA 2018 reading skills, a dynamic structure has been developed based on the correctness of the answers given by the student to the previous questions (OECD, 2019b).

\subsubsection{Independent Variables}

The Students' Hindering Questionnaire was introduced by PISA experts and consists of six items, and it was prepared on a four-point Likert type scale. The items were taken from the school principals' questionnaire SC061. The items about students' hindering behaviors are: "student truancy", "students skipping classes", "students lacking respect for teachers", "student use of alcohol or illegal drugs", "students intimidating or bullying other students", "students not being attentive". Validity and reliability analyses of the data were conducted. According to the analysis, Cronbach's Alpha coefficient was found to be .86. If Cronbach's Alpha coefficient is between .70 and .90, it seems to be a perfect result (Taber, 2018). Confirmatory Factor Analysis (CFA) was performed on the scale. As a result of the analysis, it was observed that the $x^{2} / \mathrm{sd}$ ratio was $5.0(17.844 / 8=2.23)$ and the RMSEA value was .081 . In addition, $\mathrm{CFI}=.98, \mathrm{GFI}=.95$ and $\mathrm{SRMR}=.038$. Fit indices were at a good level (Kline, 2010).

The Teachers' Hindering Questionnaire was introduced by PISA experts and consists of five items, and it was prepared as a four-point Likert type scale (strongly disagree, disagree, agree, strongly agree). The items were taken from the school principals' questionnaire SC061. The items about teachers' hindering behaviors are: "teachers not meeting individual students' needs", "teacher absenteeism", "staff resisting change", "teachers being too strict with students", "teachers not being well prepared for classes". Validity and reliability analyses of the data were done. According to the analysis, Cronbach's Alpha coefficient was found as .78. If Cronbach's Alpha coefficient is between .70 and .90, it seems to be a good result (Taber, 2018). Confirmatory Factor Analysis (CFA) was performed on the scale. As a result of the analysis, it was observed that the $x^{2} /$ sd ratio was $5.0(4.65 / 5=0.93)$ and the RMSEA value was .000 . In addition, $\mathrm{CFI}=1.00, \mathrm{GFI}=1.00$ and $\mathrm{SRMR}=.025$. Fit indices were at a good level (Kline, 2010).

The Parents' Support Questionnaire was introduced by PISA experts and consists of three items, and it was prepared as a four-point Likert type scale (strongly disagree, disagree, agree, strongly agree). The items were taken from the students' questionnaire. The items about parental support are: "my parents support my educational efforts and achievements.", "my parents support me when I am facing difficulties at school.", "my parents encourage me to be confident". Validity and reliability analyses of the data were done. According to the analysis, Cronbach's Alpha coefficient was found as .91. If Cronbach's Alpha coefficient is between .70 and .90, it seems to be a good result (Taber, 2018). Confirmatory Factor Analysis (CFA) was performed on the scale. As a result of the analysis, it was observed that the $\mathrm{x} 2 / \mathrm{sd}$ ratio was 5.0 and the RMSEA value was .000 . In addition, CFI $=1.00$, GFI $=1.00$ and 
SRMR $=.000$. Fit indices were at a good level (Kline, 2010).

Students' Gender and SES: PISA questionnaires give information about the students' genders and other variables related to students such as the education level of the mother, the education level of the father, the monthly income of the family, the number of people in the student's home and the number of books. PISA experts use these factor scores to determine the SES variable.

\subsection{Data Analyses}

The research hypotheses were analyzed by using Mplus 6.12 software. The data showed normal distribution based on the examination of the skewness and kurtosis coefficients and histogram, box-line and Q-Q graphs. The skewness and kurtosis coefficients of the groups were between -2 and +2 (George \& Mallery, 2010), and the points were close to the 45-degree reference line on the Q-Q plots. In light of this information, the scores did not show a significant deviation from the normal distribution. Cronbach Alpha $(\alpha)$ reliability co-efficient was calculated. Pearson correlation was conducted to examine whether there was a relationship among the variables. Multilevel structural modeling (MSEM) by using it with latent variables (Muthén \& Muthén, 2010) was performed. The primary assumption of this analysis was that teachers and school data were more homogeneous in themselves than in other schools (Raudenbush \& Bryk, 2002). MSEM is used for unbiased estimates for the relationship among variables. This method decreases bias in the estimation of direct and indirect effects and ensures accuracy in confidence interval (CI) coverage (Preacher et al., 2011). The Bayesian estimation method (in Mplus) was employed to strengthen the test of significance of effects. Ten thousand iterations were used for this estimation, using items as observed and main constructs as latent variables. This model included students' genders, SES and parental support at the student level (Level 1). At the school level, the variables used were teachers' hindering, students' hindering, parental support and SES. The fit indices used included chi-square, degree of freedom (df), RMSEA, SRMR, CFI, and TLI values (Hu \& Bentler, 1999).

\section{Findings}

Figure 3 and 4 indicated the results of the SEM model based on the variables in the research. At the student level, the findings indicate that there are relationships between students' gender, SES, parents' support and their literacy scores (Figure 3). At the school level, the findings also show that there are relationships between SES, parents support, teachers' hindering behaviors, students' hindering behaviors and their literacy scores (Figure 4).

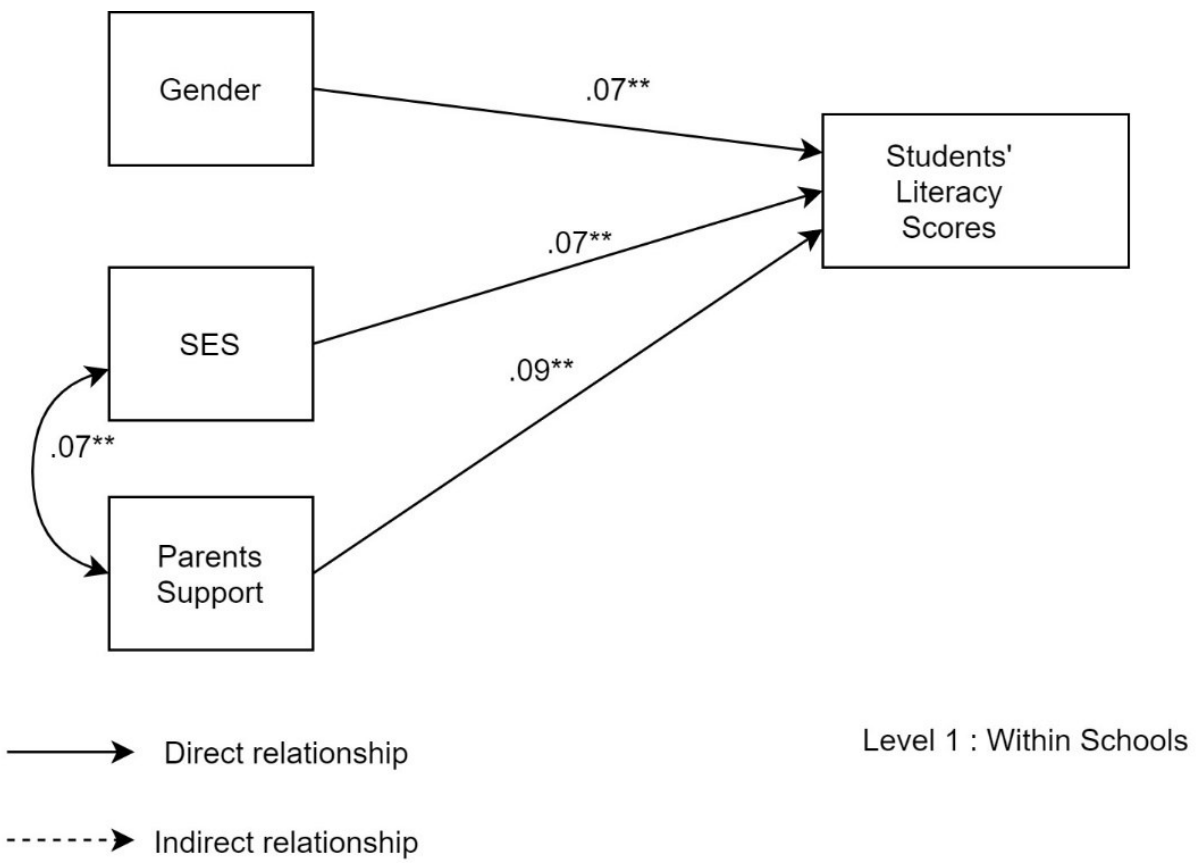

Figure 3. Results of the Model (Student level) 


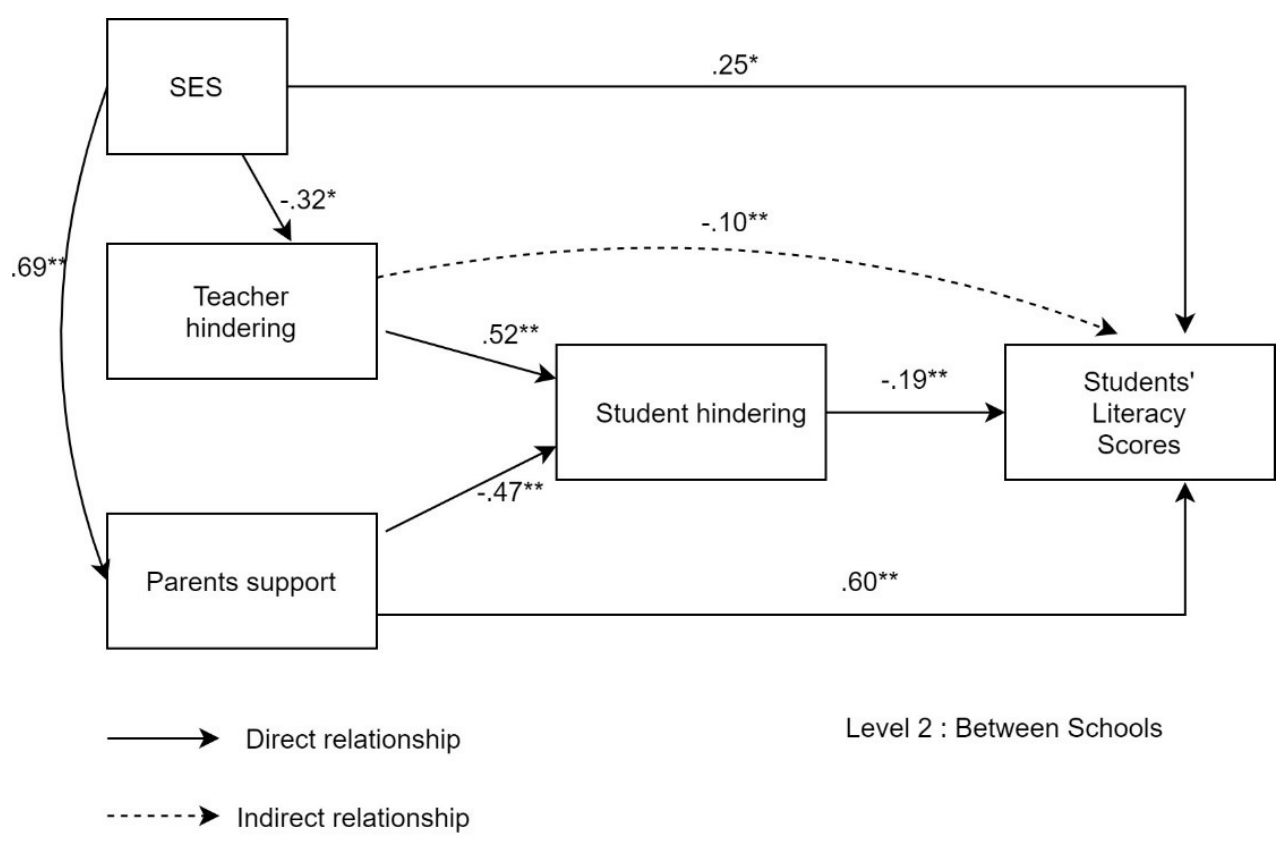

Figure 4. Results of the Model (School level)

Table 1. MSEM Estimates, Standard Errors and Confidence Intervals for the Model

\begin{tabular}{|c|c|c|c|c|}
\hline \multirow{2}{*}{ Construct } & \multicolumn{2}{|c|}{ Coefficient } & \multirow{2}{*}{ Estimate/SE } & \multirow{2}{*}{$p$} \\
\hline & Estimate & SE & & \\
\hline \multicolumn{5}{|l|}{ Direct effects (Student level) } \\
\hline Gender $\rightarrow$ Stu. Literacy & .074 & .015 & 4.875 & .00 \\
\hline SES $\rightarrow$ Stu. Literacy & .068 & .013 & 4.984 & .00 \\
\hline Parents $\rightarrow$ Stu. Literacy & .086 & .013 & 6.622 & .00 \\
\hline Parents $\leftrightarrow$ SES & .073 & .014 & 5.391 & .00 \\
\hline \multicolumn{5}{|l|}{ Direct effects (School level) } \\
\hline SES $\rightarrow$ Stu. Literacy & .272 & .094 & 2.901 & .00 \\
\hline Stu. Hin. $\rightarrow$ Stu. Literacy & -.190 & .055 & -3.480 & .00 \\
\hline Parents $\rightarrow$ Stu. Literacy & .593 & .101 & 5.847 & .00 \\
\hline SES $\rightarrow$ Stu. Hin. & .113 & .119 & 0.949 & .34 \\
\hline Parent $\rightarrow$ Stu. Hin. & -.446 & .129 & -3.453 & .00 \\
\hline Teacher Hin. $\rightarrow$ Stu. Hin. & .514 & .059 & 8.706 & .00 \\
\hline SES $\rightarrow$ Teacher Hin. & -.280 & .118 & -2.370 & .02 \\
\hline Parent $\rightarrow$ Teacher Hin & .207 & .140 & 1.477 & .14 \\
\hline SES $\rightarrow$ Parent & .655 & .071 & 9.175 & .00 \\
\hline \multicolumn{5}{|l|}{ Indirect effects } \\
\hline $\begin{array}{l}\text { Teacher Hin. } \rightarrow \text { Stu. Hin. } \rightarrow \text { Stu. } \\
\text { Literacy }\end{array}$ & -.097 & .028 & -3.464 & .00 \\
\hline Parent $\rightarrow$ Stu. Hin. $\rightarrow$ Stu. Literacy & .085 & .024 & 3.485 & .00 \\
\hline \multicolumn{5}{|l|}{ Total indirect effect } \\
\hline Teacher Hin. $\rightarrow$ Stu. Literacy & -.097 & .028 & -3.464 & .00 \\
\hline Parent $\rightarrow$ Stu. Literacy & .065 & .022 & 2.880 & .00 \\
\hline
\end{tabular}

As is seen in Table 1 and Figure 3 and 4, at the individual student level, female students' reading literacy scores were higher than those of male students $(\beta=.07, \mathrm{p}<.05)$, confirming Hypothesis 1 . This means that, on average, female students have higher perceptions of their comprehending ability and get higher scores than male students. There is a significant relationship between students' SES (Hypotheses 2 and 5) and their reading literacy scores at student level $(\beta=.07, \mathrm{p}>.05)$ and at school level $(\beta=.25, \mathrm{p}>.05)$, implying that students with higher SES backgrounds have 
higher academic performance. Parental support (Hypotheses 3 and 7a) has a positive impact on students' reading literacy scores at an individual level $(\beta=.09, \mathrm{p}>.05)$ and between schools $(\beta=.60, \mathrm{p}>.05)$, suggesting that parental support greatly helps students improve their academic achievement and makes students successful in their school life. Additionally, there is a significant relationship between parental support and SES at the student level $(\beta=.09, p>.05)$ and $(\beta=.69, p>.05)$, proving Hypotheses 4 and $5 \mathrm{a}$. This claims that families with higher SES are more sensitive to supporting their children's academic life.

Between schools, students' SES has a significant and negative direct effect on teachers' hindering behaviors $(\beta=$. $-32, \mathrm{p}<.05)$, confirming Hypothesis $5 \mathrm{~b}$. This finding suggests that families with higher SES can force teachers to exhibit less hindering behaviors because they are more sensitive to their students' school life. Additionally, teacher hindering behaviors (Hypothesis 6) have a positive and significant direct impact on students' hindering behaviors $(\beta=.52, \mathrm{p}<.05)$, presumably because teachers' hindering behaviors increase students' hindering behaviors in their classroom. Teachers' hindering behaviors also have an indirect negative impact on students' reading literacy scores $(\beta=.-10, p<.05)$, proving Hypothesis $6 \mathrm{a}$. This finding illustrates that teachers' hindering behaviors disrupt the classroom learning environment. For this reason, students cannot obtain qualified learning outcomes. Moreover, parental support impacts students' hindering behaviors negatively $(\beta=.52, \mathrm{p}<.05)$, supporting Hypothesis 7 . This means that families with supportive attitudes can block their children's bad behaviors and encourage them to focus on their school lives. The last hypothesis (Hypothesis 8) expresses that there is a relationship between students' hindering behaviors and their reading literacy scores. Students' hindering behaviors have a negative influence on their reading scores $\beta=-.19, \mathrm{p}<.05$ ). School-level variables explained $78 \%$ of students' literacy scores. As a result, the hypothesis was proved and the student level and school level variables have a relationship to the students' reading scores.

\section{Discussion}

In this part, a general evaluation of the Turkish students' reading skills in PISA 2018 was given. After that, the interpretation of the main findings was discussed, then limitations of the study were debated and, finally, the paper was concluded with recommendations for policy, practice and future research.

Turkey is one of the ten countries where the difference between the schools is the highest in the area of reading skills. In terms of between school performance differences, Turkey is below the OECD average. Thus, Turkey shows a significant change in the performance levels of students between schools but changes in the schools are limited. Turkey's second level and ratio of students in the reading skills field, showed a 13.9\% increase compared to the PISA 2015 results and reached $73.9 \%$. In addition, there was a significant increase in student ratios at higher levels of proficiency. The ratio of students at the fourth level of competence has increased from $5.7 \%$ to $13.5 \%$, and the ratio of students at the fifth level of proficiency has increased from $0.6 \%$ to $3.1 \%$. Turkish students' average of the mean scores in reading skills is 466 , although in similar participating countries and economies, it was 453 Turkey ranks $40^{\text {th }}$ in reading skills out of 79 countries, and 31 st among the 37 OECD countries. Turkey was the second country to show the highest increase in reading skill average scores in PISA 2018 (MEB, 2019).

The first hypothesis predicted a significant relationship between students' genders and their literacy scores. The research findings indicate that female students are more successful than male students. This means that female students have a stronger belief in their capability to achieve in learning practices and perform well in their teaching practices. This research finding supports the results of previous studies (Charles \& Luoh, 2003; Freeman, 2004; Machin \& Mc Nally, 2005; Onuk, 2007), which provided evidence that female students have higher scores than male teachers. The reason for this could be explained by the differences in the gender contexts. Female students tend to study more responsibly than male students. Especially in developing countries such as Turkey, female students should study harder because, in their future lives, it is very hard for them to get a job and they are perfect at managing time (Demirtaş \& Özer, 2007; Nelson \& Nelson, 2003). Therefore, this challenge and capability makes them perform well in school practices.

The second and fifth hypotheses predicted that students' SES would have a statistically significant effect on their reading literacy scores. The research results suggest the hypothesis is correct. Previous research findings pointed out that students' SES has a significant impact on their academic achievement (Brown et al., 2016; Buckingham et al., 2013; Hanushek, 1997; Özdemir, 2019; Sirin, 2005). These studies show that the academic skills of the students with a low socio-economic level are less than those with a high socio-economic level. In their families, parents have higher educational status and they also want their children to be well educated and have good jobs so they monitor their children's educational lives closely (Abotsi et al., 2018). 
The third assumption was that a positive relationship would exist between parental support and students' academic achievement (Hypothesis 3 and Hypothesis 7a). The results of the analysis supported this assumption. The finding is supported by the previous literature (Arslanargun, 2007; Gonida \& Cortina, 2014). They expressed the opinion that the main reason for parents' lack of interest is based on not establishing a healthy communication with their children early in their development. According to them, parents do not care enough about their children's psycho-social and cognitive development and just take care of their biological needs. They also underlined that parents should motivate their children and they should oversee their children's homework and their school life closely.

The results also provide evidence to support the fourth hypothesis and Hypothesis 5a, claiming that there is a positive significant relationship between SES and parental support. This finding is parallel to the results of the previous studies (Chiu \& Xihua, 2008; Çiftçi \& Çağlar, 2014; OECD, 2019a). The studies state that the families with high SES can increase their children's learning abilities by providing more material for the school and focusing on school-related activities. Additionally, they have opportunities to provide the physical and cultural development of their children. In other words, parents who have a high SES level show that they are well-educated, conscientious about education and they are aware how to support their children in their school lives.

The fifth finding states that SES has a negative and significant direct effect on teacher hindering behaviors. This demonstrates that students with a higher SES level would block teachers' hindering behaviors because most of these students are also successful in their classroom activities and this circumstance make teachers more motivated. In other words, they force them to be eager to show a high performance in their classes. Moreover, studies underlined that we see teachers' hindering behaviors less in the schools in the regions where the socio- economic level is high because, in these regions, parents are conscientious and can create hidden pressures on teachers and the school. This finding is parallel to those of several previous studies (Helstad \& Lund, 2012; Vangrieken, Dochy, Raes, \& Kyndt, 2015). These studies claim that SES is one of the vital factors that decreases teachers' hindering behaviors. Teachers show the hindering behaviors mostly because of professional burnout, lack of motivation and an unhealthy learning climate. However, if they are motivated and they have a supportive learning climate, they avoid showing hindering behaviors.

The sixth hypothesis suggests that teachers' hindering behaviors have a significant impact on students' hindering behaviors. This indicates that, if teachers neglect individual students' needs, are often absent, resist change and have poor preparation for classes, these hindering behaviors trigger students' hindering behaviors. This result is supported by previous studies (Gajda \& Koliba, 2008; Goddard et al., 2007). These studies claim that teachers' negative attitudes make students unsuccessful in their school lives. Moreover, students' devotion to school would decrease and some of them would leave their schools because of these negative attitudes. On the other hand, supportive and motivating behaviors of teachers increase students' commitment to school and their academic success. The other hypothesis about teachers' hindering behaviors states that teachers' hindering behaviors impact on student achievement indirectly. The finding proves this hypothesis. Teachers' hindering behaviors have a negative and indirect effect on student achievement via students' hindering behaviors. Teachers' negative behaviors cause an unhappy atmosphere in their classes. As a result, students exhibit negative attitudes and behaviors, then they begin to ignore their academic lives and be unsuccessful.

The seventh hypothesis claims that parental support influences students' hindering behaviors in a negative way. This result overlaps with Ong, Phinney and Dennis' (2006), and Gonida and Cortina's (2014) studies which provided evidence that creating a culture of trust between parents and their children encourages them to be successful in their school lives.

This means that parents who are open to communication, open-hearted, supportive, cooperative and dynamic in facilitating students' learning processes can quickly build relational trust with their children; thus, they can easily overcome the problems they face in their school lives. Prior studies have emphasized that parents do not care enough about their children's psycho-social and cognitive development and just take care of their biological needs. Instead, parents should motivate their children and they should monitor their children's homework and their school lives closely (Chen, 2008; Gottfried et al., 1994; Wentzel, 1998). If parents neglect their children's needs and fail to focus on their psycho-social and cognitive development, they cause children to behave negatively. As a result of a lack of supportive behaviors, children can begin to use illegal drugs and drop out of their schools.

Finally, the findings provide evidence to suggest that there is a direct and negative relationship between students' hindering behaviors and their academic achievement. This finding supports the available literature, which indicates that students' hindering behaviors influence their academic scores negatively (Barutçu Yıldırım, \& Demir, 2019; Török, Szabó, \& Tóth, 2018). These studies emphasized that students' hindering behaviors have negative effects on 
their academic performance and well-being. Additionally, these negative behaviors cause students to drop out of their schools. To block this effect, parents, teachers and principals should invest a great deal of effort into creating supportive, peaceful and motivating learning climates for children.

School principals, teachers, parents and the students have a great responsibility in order for the students to be successful and become well-educated individuals in the future. The paper tried to reveal the roles of school actors and modeled the effects of student-level and school-level variables for quality education and quality school outcomes. Now, after interpreting the study's findings, it is important to acknowledge the limitations of the current research. First, there is no data on leadership style of Turkish school principals in PISA 2018. In the model, the effects of school principals on students' reading skill scores are not given but this is the limitation of the study. Turkish policy makers should insist on collecting data on leadership styles. Secondly, proportionate sampling ensured a sample that represented the entire national population. In this paper, it is a mediation model using cross-sectional data, which could lead to biased estimates of the coefficients (Maxwell \& Cole, 2007). To minimize these limitations, the Bayesian estimation method was used and, therefore, the calculation of direct and indirect effects is strengthened. Thirdly, this is a quantitative research and it just puts forward the relationships among some variables. In order to obtain a deeper knowledge, researchers should conduct qualitative studies. These further studies would spread more light on the effects of the student level and school level variables on student achievement.

\section{References}

Abotsi, A. K., Yaganumah, N., \& Obeng, H. E. (2018). Dropouts issues and its economic implications: Evidence from rural communities in Ghana. Journal of Economics and Economic Education Research, 19(1), 1-13.

Aikens, N. L., \& Barbarin, O. (2008). Socioeconomic differences in reading trajectories: The contribution of family, neighborhood, and school contexts. Journal of Educational Psychology, 100(2), 235. https://doi.org/10.1037/0022-0663.100.2.235

Akin, A. (2012). Self-handicapping and burnout. Psychological Reports, 110(1), 177-196. https://doi.org/10.2466/01.02.14.PR0.110.1.187-196

Aslanargun, E. (2007). Okul-aile işbirliği ve öğrenci başarısı üzerine bir tarama çalışma. Manas Üniversitesi Sosyal Bilimler Dergisi, 9(18), 119-135.

Barro, R. J. (2013). Health and economic growth. Annals of Economics and Finance, 14(2), 329-366.

Barro, R. J., \& Lee, J. W. (2013). A new data set of educational attainment in the world, 1950-2010. Journal of Development Economics, 104, 184-198. https://doi.org/10.1016/j.jdeveco.2012.10.001

Barutçu Yıldırım, F., \& Demir, A. (2019). Self-handicapping among university students: The role of procrastination, test anxiety, self-esteem, and self-compassion. Psychological Reports. https://doi.org/10.1177/0033294118825099

Bellibas, M. S. (2016). Who Are the Most Disadvantaged? Factors Associated with the Achievement of Students with Low Socio-Economic Backgrounds. Educational Sciences: Theory and Practice, 16(2), 691-710.

Brown, M., Wohn, D., \& Ellison, N. (2016). Without a map: College access and the online practices of youth from $\begin{array}{lllll}\text { low-income communities. } \quad \text { Computers } \quad \& \quad \text { Education, } & 92, & \text { 104-106. }\end{array}$ https://doi.org/10.1016/j.compedu.2015.10.001

Bryk, A. S., Sebring, P. B., \& Allensworth, E. (2010). Organizing schools for improvement: Lessons from Chicago. Chicago: University of Chicago Press. https://doi.org/10.7208/chicago/9780226078014.001.0001

Buckingham, J., Wheldall, K., \& Beaman-Wheldall, R. (2013). Why poor children are more likely to become poor readers: The school years. Australian Journal of Education, 57(3), 190-213. https://doi.org/10.1177/0004944113495500

Carneiro, P. (2008). Equality of opportunity and educational achievement in Portugal. Portuguese Economic Journal, 7(1), 17-41. https://doi.org/10.1007/s10258-007-0023-z

Charles, K., \& Luoh, M.-C. (2003). Gender differences in completed schooling. Review of Economics and Statistics, 85(3), 559-77. https://doi.org/10.1162/003465303322369722

Chen, J. J. L. (2008). Grade-level differences: Relations of parental, teacher and peer support to academic engagement and achievement among Hong Kong students. School Psychology International, 29(2), 183-198. 
https://doi.org/10.1177/0143034308090059

Chiu, M. M., \& Xihua, Z. (2008). Family and motivation effects on mathematics achievement: Analyses of students in 41 countries. Learning and Instruction, 18, 321-336. https://doi.org/10.1016/j.learninstruc.2007.06.003

Çiftçi, C., \& Çağlar, A. (2014). Ailelerin sosyo ekonomik özelliklerinin öğrenci başarısı üzerindeki etkisi Fakirlik kader midir? International Journal of Human Sciences, 11(2), 155-175. https://doi.org/10.14687/ijhs.v11i2.2914

Daniel, J. (2012). Choosing the type of probability sampling. In: Daniel J (Ed.), Sampling Essentials: Practical Guidelines for Making Sampling Choices. Thousand Oaks, California: SAGE Publications, Inc. https://doi.org/10.4135/9781452272047

Darling-Hammond, L., \& Young, P. (2002). Defining "highly qualified teachers:" What does "scientifically-based research" actually tell us? Educational Researcher, 31, 13-25. https://doi.org/10.3102/0013189X031009013

Darling-Hammond, L. (2000). Teacher quality and student achievement. Education Policy Analysis Archives, 8, 1-44. https://doi.org/10.14507/epaa.v8n1.2000

Dee, T. S. (2007). Teachers and the gender gaps in student achievement. Journal of Human Resources, 42(3), 528-554. https://doi.org/10.3368/jhr.XLII.3.528

Demirtaş, H., \& Özer, N. (2007). Öğretmen adaylarının zaman yönetimi becerileri ile akademik başarısı arasındaki ilişkisi. Eğitimde Politika Analizleri ve Stratejik Araştırmalar Dergisi, 2(1), 34-47.

Freeman, C. E. (2004). Trends in educational equity of girls and women, national center for education statistics. US Department of Education: Institute of Education Sciences.

Gajda, R., \& Koliba, C. J. (2008). Evaluating and improving the quality of teacher collaboration: A field-tested framework for secondary school leaders. NASSP Bulletin, 92, 133-153. https://doi.org/10.1177/0192636508320990

George, D., \& Mallery, P. (2010). SPSS for Windows step by step. A simple study guide and reference (10th ed.). GEN, Boston, MA: Pearson Education, Inc.

Goddard, Y. L., Goddard, R. D., \& Tschannen-Moran, M. (2007). A theoretical and empirical investigation of teacher collaboration for school improvement and student achievement in public elementary schools. Teachers College Record, 109, 877-896.

Goldin, C., \& Katz, L. F. (2008). Mass secondary schooling and the state: the role of state compulsion in the high school movement. In Understanding long-run economic growth: Geography, institutions, and the knowledge economy. Chicago: University of Chicago Press, 275-310. https://doi.org/10.7208/chicago/9780226116426.003.0010

Gonida, E. N., \& Cortina, K. S. (2014). Parental involvement in homework: Relations with parent and student achievement-related motivational beliefs and achievement. British Journal of Educational Psychology, 84(3), 376-396. https://doi.org/10.1111/bjep.12039

Gottfried, A. E., Fleming, J. S., \& Gottfried, A. W. (1994). Role of parental motivational practices in children's academic intrinsic motivation and achievement. Journal of Educational Psychology, 86, 104-113. https://doi.org/10.1037/0022-0663.86.1.104

Harris, D. N., \& Sass, T. R. (2011). Teacher training, teacher quality and student achievement. Journal of public economics, 95(7-8), 798-812. https://doi.org/10.1016/j.jpubeco.2010.11.009

Hanushek, E. A. (1997). Assessing the effects of school resources on student performance: An update. Educational Evaluation and Policy Analysis, 19(2), 141-164. https://doi.org/10.3102/01623737019002141

Heck, R. H., \& Hallinger, P. (2010). Testing a longitudinal model of distributed leadership effects on school improvement. The Leadership Quarterly, 21(5), 867-885. https://doi.org/10.1016/j.leaqua.2010.07.013

Helstad, K., \& Lund, A. (2012). Teachers' talk on students' writing: Negotiating students' texts in interdisciplinary teacher teams. Teaching and Teacher Education, 28, 599-608. https://doi.org/10.1016/j.tate.2012.01.004

Hendron, M., \& Kearney, C. A. (2016). School climate and student absenteeism and internalizing and externalizing behavioral problems. Children \& Schools, 38(2), 109-116. https://doi.org/10.1093/cs/cdw009

Hindman, J., \& Stronge, J. (2009). The \$2 million decision: Teacher selection and principals' interviewing practice. 
Educational Research Service Spectrum, 27, 1-10.

Hoge, D. R., Smit, E. K., \& Hanson, S. L. (1990). School experiences predicting changes in self-esteem of sixth- and seventh-grade students. Journal of Educational Psychology, 82(1), 117-127. https://doi.org/10.1037/0022-0663.82.1.117

Hoy, W. K., Smith, P. A., \& Sweetland, S. R. (2002). The development of the organizational climate index for high schools: Its measure and relationship to faculty trust. The High School Journal, 86(2), 38-49. https://doi.org/10.1353/hsj.2002.0023

Hu, L. T., \& Bentler, P. M. (1999). Cutoff criteria for fit indexes in covariance structure analysis: Conventional criteria versus new alternatives. Structural Equation Modeling: A Multidisciplinary Journal, 6(1), 1-55. https://doi.org/10.1080/10705519909540118

Kızıldağ, A. (2009). Teaching English in Turkey: Dialogues with teachers about the challenges in public primary schools. International Electronic Journal of Elementary Education, 1(3), 188-201.

Kline, R. (2010). Principles and practice of structural equation modeling (3rd ed.). New York, NY: Guilford.

Klomegah, R. Y. (2007). Predictors of Academic Performance of University Students: An Application of the Goal Efficacy Model. College Student Journal, 41(2).

Koutsoulis, M. K., \& Campbell, J. R. (2001). Family processes affect students' motivation, and science and math achievement in Cypriot high schools. Structural Equation Modeling, 8(1), 108-127. https://doi.org/10.1207/S15328007SEM0801_6

LaRusso, M., Romer, D., \& Selman, R. (2008). Teachers as builders of respectful school climates: Implications for adolescent drug use norms and depressive symptoms in high school. Journal of Youth \& Adolescence, 37, 386-398. https://doi.org/10.1007/s10964-007-9212-4

Leonard, L. (2002). Schools as professional communities: Addressing the collaborative challenge. International Electronic Journal for Leadership in Learning, 6.

Machin, S., \& McNally, S. (2005). Gender and student achievement in English schools. Oxford Review of Economic Policy, 21(3), 357-372. https://doi.org/10.1093/oxrep/gri021

Maxwell, S. E., \& Cole, D. A. (2007). Bias in cross-sectional analyses of longitudinal mediation. Psychological methods, 12(1), 23. https://doi.org/10.1037/1082-989X.12.1.23

MEB. (2019). PISA 2018 Türkiye ön raporu. Ankara: MEB.

Muthen, L. K., \& Muthen, B. O. (2012). Mplus users' guide: Statistical analysis with latent variables (7th ed.). Los Angeles, CA: Muthen \& Muthen.

Nelson, D. B., \& Nelson, K. W. (2003, March). Emotional intelligence skills: Significant factors in freshmen achievement and retention. Paper presented at the American Counselling Association Conference, Anaheim, CA.

OECD. (2019a). PISA 2018 results. Paris: OECD.

OECD. (2019b). PISA 2018 Assessment and Analytical Framework. Paris: OECD Publishing.

Ong, A. D., Phinney, J. S., \& Dennis, J. (2006). Competence under challenge: Exploring the protective influence of parental support and ethnic identity in Latino college students. Journal of Adolescence, 29(6), 961-979. https://doi.org/10.1016/j.adolescence.2006.04.010

Onuk, Ö. (2007). Müzik ögretmenliği lisans programı ögrencilerinin ögretmenliğe güdülenmeleri ile akademik başarlları arasındaki ilişki (Yayınlanmamış Doktora Tezi). Gazi Üniversitesi Eğitim Bilimleri Enstitüsü Güzel Sanatlar Ana Bilim Dalı Müzik Eğitimi Bilim Dalı. Ankara.

Özdemir, M., \& Demircioglu, E. (2015). Distributed leadership and contract relations: Evidence from Turkish high schools. Educational Management Administration \& Leadership 43(6), 918-938. https://doi.org/10.1177/1741143214543207

Özdemir, N. (2019). Principal leadership and students' achievement: Mediated pathways of professional community and teachers' instructional practices. KEDI Journal of Educational Policy, 16(1), 81-104.

Özgüngör, S. (2010). Relationship between university students' cheating behaviuors and their perceptions of teacher and student characteristics. Education and Science, 33(149), 68-79. 
Patterson, M., Perry, E., Decker, C., Eckert, R., Klaus, S., \& Wendling, L., et al. (2003). Factors associated with high school mathematics performance in the United States. Studies in Educational Evaluation, 29(2), 91-108. https://doi.org/10.1016/S0191-491X(03)00017-8

Pomerantz, E. M., Ng, F. F., \& Wang, Q. (2006). Mothers' mastery-oriented involvement in children's homework: Implications for the well-being of children with negative perceptions of competence. Journal of Educational Psychology, 98, 99-111. https://doi.org/10.1037/0022-0663.98.1.99

Pomerantz, E. M., Wang, Q., \& Ng, F. F. (2005). Mothers' affect in the homework context: The importance of staying positive. Developmental Psychology, 41, 414-427. https://doi.org/10.1037/0012-1649.41.2.414

Preacher, K. J., Zhang, Z., \& Zyphur, M. J. (2011). Alternative methods for assessing mediation in multilevel data: The advantages of multilevel SEM. Structural Equation Modeling, 18(2), 161-182. https://doi.org/10.1080/10705511.2011.557329

Raudenbush, S. W., \& Bryk, A. S. (2002). Hierarchical linear models: Applications and data analysis methods. Thousand Oaks, CA: Sage Publications, Inc.

Robinson, V. M. J., Lloyd, C., \& Rowe, K. (2008). The impact of leadership on student outcomes: An analysis of the differential effects of leadership types. Educational Administration Quarterly, 44(5), 635-674. https://doi.org/10.1177/0013161X08321509

Rone, B. C. (2009). The impact of the data team structure on collaborative teams and student achievement (Doctoral dissertation). Available from ProQuest Dissertations and Theses database. (UMI NO. 3397293).

Sarıer, Y. (2016). Türkiye'de öğrencilerin akademik başarısını etkileyen faktörler: Bir meta-analiz çalışması. Hacettepe Üniversitesi Ë̆itim Fakültesi Dergisi, 31(3), 609-627. https://doi.org/10.16986/HUJE.2016015868

Schab, F. (1991). Schooling without learning: Thirty years of cheating in high school. Adolescence, 26(104), 839-847.

Schoen, L. T., \& Teddlie, C. (2008). A new model of school culture: A response to a call for conceptual clarity. School Effectiveness and School Improvement, 19(2), 129-153. https://doi.org/10.1080/09243450802095278

Sirin, S. R. (2005). Socioeconomic status and academic achievement: A meta-analytic review of research. Review of Educational Research, 75(3), 417-453. https://doi.org/10.3102/00346543075003417

Smetser, F. (2007). Samenwerken in teams, een vanzelfsprekendheid? Een onderzoek naar condities die het samenwerken van professionals in teams beïnloeden [Cooperating in teams as taken for granted? Research into conditions that influence the cooperation of professionals in teams] (Doctoral dissertation). Retrieved from http://dare.ubn.kun.nl/

Smith, L., Sinclair, K. E., \& Chapman, E. S. (2002). Students' goals, self-efficacy, self-handicapping, and negative affective responses: An Australian senior school student study. Contemporary Educational Psychology, 27(3), 471-485. https://doi.org/10.1006/ceps.2001.1105

Staiger, D. O., \& Rockoff, J. E. (2010). Searching for effective teachers with imperfect information. Journal of Economic Perspectives, 24, 97-118. https://doi.org/10.1257/jep.24.3.97

Sun J., \& Leithwood K. A. (2012). Transformational school leadership effects on student achievement. Leadership and Policy in Schools 11(4), 418-451. https://doi.org/10.1080/15700763.2012.681001

Taber, K. S. (2018). The use of Cronbach's alpha when developing and reporting research instruments in science education. Research in Science Education, 48(6), 1273-1296. https://doi.org/10.1007/s11165-016-9602-2

Török, L., Szabó, Z. P., \& Tóth, L. (2018). A critical review of the literature on academic self-handicapping: theory, manifestations, prevention and measurement. Social Psychology of Education, 21(5), 1175-1202. https://doi.org/10.1007/s11218-018-9460-z

Turner, I., Reynolds, K. J., Lee, E., Subasic, E., \& Bromhead, D. (2014). Well-being, school climate, and the social identity process: A latent growth model study of bullying perpetration and peer victimization. School Psychology Quarterly, 29(3), 320-335. https://doi.org/10.1037/spq0000074

Ünal, A., Yildirim, A., \& Çelik, M. (2010). İlköğretim okulu müdür ve öğretmenlerinin velilere ilişkin algılarının analizi. Selçuk Üniversitesi Sosyal Bilimler Enstitüsü Dergisi, 23, 261-272.

Üzbe, N., \& Bacanlı, H. (2015). The role of achievement goal orientation, self-esteem and academic achievement in prediction of self-handicapping. The Journal of Turkish Educational Sciences, 13(1), 33-50. 
Vangrieken, K., Dochy, F., Raes, E., \& Kyndt, E. (2015). Teacher collaboration: A systematic review. Educational Research Review, 15, 17-40. https://doi.org/10.1016/j.edurev.2015.04.002

Virtanen, M., Kivimaki, M., Luopa, P., Vahtera, J., Elovainio, M., Jokela, J., \& Pietikainen, M. (2009). Staff reports of psychosocial climate at school and adolescents' health, truancy and health education in Finland. European Journal of Public Health, 19, 554-560. https://doi.org/10.1093/eurpub/ckp032

Wentzel, K. R. (1998). Social relationships and motivation in middle school: The role of parents, teachers, and peers. Journal of Educational Psychology, 90, 202-209. https://doi.org/10.1037/0022-0663.90.2.202

Westheimer, J. (2008). Learning among colleagues: Teacher community and the shared enterprise of education. In M. Cochran-Smith, S. Feiman-Nemser, \& J. McIntyre (Eds.), Handbook of research on teacher education (pp. 756-782). Reston, VA and Lanham, MD: Association of Teacher Educators and Rowman.

Xitao, F., \& Chen, M. (2001). Parental involvement and students' academic achievement: A meta- analysis. Educational Psychology Review, 13(1), 1-22.

Yu, J., \& McLellan, R. (2019). Beyond academic achievement goals: The importance of social achievement goals in explaining gender differences in self-handicapping. Learning and Individual Differences, 69, 33-44. https://doi.org/10.1016/j.lindif.2018.11.010

\section{Copyrights}

Copyright for this article is retained by the author(s), with first publication rights granted to the journal.

This is an open-access article distributed under the terms and conditions of the Creative Commons Attribution license (http://creativecommons.org/licenses/by/4.0/). 